\title{
Evaluation of Online-Based Ride-Hailing Services Using Service Quality (Servqual) Method, Refined Kano Model, Importance Performance Analysis (IPA), and Quality Function Deployment (QFD): A Case Study of Grab Bike Indonesia
}

\author{
Dino Caesaron $^{1 *}$, Jessie Makapedua ${ }^{2}$, and Rio Prasetyo Lukodono ${ }^{3}$ \\ ${ }^{1}$ Industrial Engineering Department, Telkom University \\ Jln. Telekomunikasi Terusan Buah Batu, West Java 40257, Indonesia \\ ${ }^{2}$ Department of Industry and Commerce, North Sulawesi Provincial Government \\ Jln. Tololiu Supit 14, North Sulawesi 95119, Indonesia \\ ${ }^{3}$ Department of Industrial Engineering, Universitas Brawijaya \\ Jln. Veteran, East Java 65145, Indonesia \\ 1dinocaesaron@telkomuniversity.ac.id; 2jesmakapedua@gmail.com; ${ }^{3}$ rio_pl@ub.ac.id
}

Received: $10^{\text {th }}$ November 2020/ Revised: $10^{\text {th }}$ January 2021/ Accepted: $14^{\text {th }}$ January 2021

\begin{abstract}
How to Cite: Caesaron, D., Makapedua, J., \& Lukodono, R. P. (2021). Evaluation of Online-Based Ride-Hailing Services Using Service Quality (Servqual) Method, Refined Kano Model, Importance Performance Analysis (IPA), and Quality Function Deployment (QFD): A Case Study of Grab Bike Indonesia. ComTech: Computer, Mathematics and Engineering Applications, 12(2), 75-88. https://doi.org/10.21512/comtech.v12i2.6790
\end{abstract}

\begin{abstract}
The rapid development of the service industry in Indonesia is seen from the emergence of several companies in the transportation sector based on online applications. To compensate for the public needs of these services, the company needs to maintain customer satisfaction from the service performance. The research aimed to evaluate the quality of transportation services at Grab Bike Indonesia. By using quantitative and qualitative approach, the research applied Service Quality (Servqual) analysis for the level of perceived satisfaction, Refined Kano model for the role of each attribute to customer satisfaction, Importance Performance Analysis (IPA) for the priority of improvements, and Quality Function Deployment (QFD) for the technical steps of improvement. Servqual analysis shows 36 service attributes that need to be improved, particularly 16 service attributes with high gap scores. Furthermore, there are 5 attributes classified as major influencing attributes on customer satisfaction based on Refined Kano analysis. These factors also need to be improved in the IPA category. From the results of QFD, it suggests that the company should consider the technical steps of improvement. For example, the company should provide regulations that drivers must obey, have driving standards, strict sanctions for every violation of rules, initial training for drivers, and utilization
\end{abstract}

of GPS properly, provide an easy way for customer feedback, and others.

Keywords: online-based ride-hailing services, Service Quality (Servqual), Refined Kano, Importance Performance Analysis (IPA), Quality Function Deployment (QFD)

\section{INTRODUCTION}

The service industry has been growing rapidly in recent years. The growth is marked by the emergence of competition between companies engaged in services. It requires the ability of the company to provide the best service that can meet customers' needs to survive in the competition. It is essential for companies to produce good judgment in customers' eyes to bring up customers' comfort and loyalty to continue using the company's services. According to data obtained from the Central Intelligence Agency (CIA) in The World Fact Book (2017a), it is known that based on Gross Domestic Product (GDP) in 2017, the service industry had the biggest contribution to GDP in the world. The contribution of the service industry to world GDP was $63 \%$, followed by the manufacturing industry with $30 \%$ and the agriculture industry with $6,4 \%$. These contributions can be seen in Figure 1. 


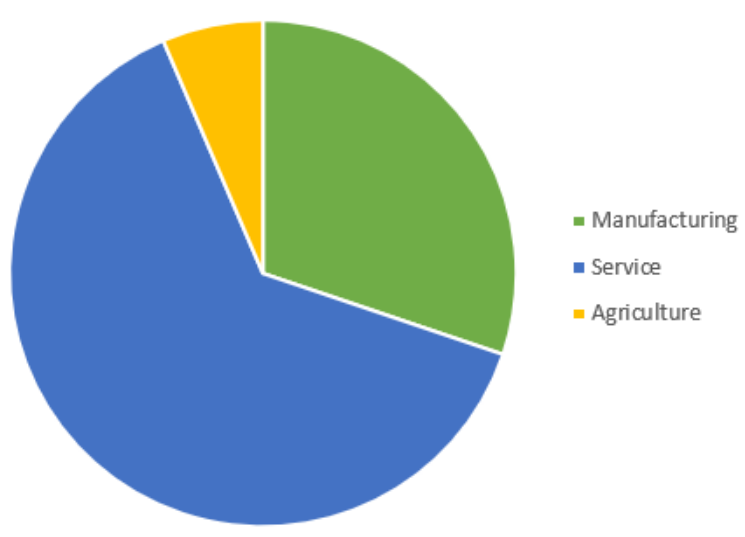

Figure 1 Contribution of Services Industries to GDP Globally

In Indonesia, the service industry sector also occupies the first position to contribute to national GDP with 45,4\% (The World Factbook, 2017b). Therefore, the service industry is currently one of the businesses that are in high demand. It also continues to be developed by companies that see good opportunities from this industry.

The service industry development in Indonesia can be seen through the emergence of several new companies engaged in services. One of the service industries that is currently developing rapidly is transportation services. It is due to the high need for transportation services which is one of the important factors to support the citizens' daily activities. It is known that DKI Jakarta is the capital of the Republic of Indonesia which is a business center as well as a government center with a population of around 10,5 million people (Badan Pusat Statistik DKI Jakarta, 2019 b). From the total population, $60 \%$ are classified as the active workforce that requires transportation as a supporting factor for their activities. These conditions indicate that the existence of the transportation sector is one of the people's needs in DKI Jakarta. It is needed to support the daily activities and can positively influence the growth of other sectors.

Apart from the people's need for transportation, several companies take advantage of technology developments that make it easier for humans to run their businesses. Some companies, such as Grab, Gojek, and others, attract people of all ages because the transportation services offered make it easy for users. The transportation service is carried out by utilizing the sophistication of communication technology on smartphones so that users can place orders online by using applications that can be downloaded on many types of Android smartphones. The development of enthusiasts in this field does not only occur in its customers but also the utilization of human resources, characterized by an increase in interest in work related to the transportation sector. It is caused by the opening of new jobs that anyone can do as a main job and side job, with the main requirements of having a private motorized vehicle and driving the vehicle properly.

Based on data from Badan Pusat Statistik DKI Jakarta (2019a), it is known that the highest number of motorized vehicles is the motorcycle. The community still chooses motorcycle because it is efficient in terms of cost and time. The public is more interested in using motorcycles as private vehicles and as an option in the vehicle types in the online application of transportation services. The number of ownerships of this type of two-wheeled vehicle also affects the number of job enthusiasts as motorcycle drivers in the transportation service. A large number of job seekers in this online application-based transportation service has positive and negative effects. People from various places compete to take the opportunity in this line of work because it can fill their leisure time rather than being unemployed. However, there is a problem with fewer professional drivers. For example, some drivers often violate traffic rules, lack good driving standards to maintain customers' comfort, are less careful in traveling to take the customers, and refuse customers' orders.

Currently, there are often customers' complaints about online transportation services. The issues show customer dissatisfaction, which needs to be fixed by the company to bring customers' loyalty. To have the most optimized result, the company needs an appropriate improvement method. Therefore, further investigation is needed through similar research regarding service quality improvement. In general, improvement can be started by evaluating the gaps between customers' requirements and the current service. Furthermore, it can be seen from customers' criticisms and suggestions after using the services offered. In addition, the company also needs to understand and pay attention to what customer wants because the customer holds a significant role in determining the service value.

In order to solve the problems specifically, the research applies the Service Quality (Servqual) method (Paquette, Cordeau \& Laporte, 2009). The research is conducted by studying customers' needs based on the quality attributes of existing services. It determines customers' expected needs for the services offered, which will be assessed with the current situation.

The research analyzes the importance of the quality attributes of the transportation services offered by Grab Bike Indonesia to customer satisfaction using the Refined Kano Model to give a proposal to improve the quality of transportation services at Grab Bike Indonesia. This model will consider the degree of importance of each service quality attribute. Then, it is followed by using the Importance and Performance Analysis (IPA) method to direct Grab Bike Indonesia in carrying out service quality improvement in accordance with the priority interests of customers. At the end of the research, optimization will be carried out through structured improvement steps using the Quality Function Deployment (QFD) method.

According to Nasution, as stated in Puspitasari, Suliantoro, and Kusumawardhani (2010), service quality is the level of expected excellence and 
control over the level of excellence to meet customer desires. With the Servqual analysis, improvements can be made if there are gaps between the value of expectations and customer satisfaction. Therefore, quality improvements can be realized through the level of customer satisfaction. It is necessary to evaluate a level of customer satisfaction with the services offered to improve service quality. The customer is the object of every service performed. So, the customer is also the one who can make a real assessment of the service performance.

Kano model is one of the most widely used models to date to improve service quality. Kano model presents the different functions of each service attribute in providing customer satisfaction. It is divided into five categories of quality attributes (Yang, 2005). First, there is an attractive quality attribute (pleasure attribute). The level of customer satisfaction will increase following the increase in attribute performance. However, a decrease in attribute performance will not cause a decrease in the level of satisfaction. Second, it is a one-dimensional quality attribute (expected attribute). The performance of an attribute is linearly related to customer satisfaction. Customer satisfaction will increase more if the attribute performance is in accordance with customers' desires. Similarly, satisfaction will decrease if the attribute performance does not follow customer desires. The more the attribute is functional, the more satisfied the customer will be.

Third, there is a quality attribute (basic attribute). If the attribute performance is not good, it will cause customer dissatisfaction. However, customer satisfaction will not increase significantly if the product performance has been fulfilled because the customers think that the attribute should exist. Fourth, it is an indifferent quality attribute. If the attribute does not exist, it will not affect customer satisfaction and dissatisfaction. Fifth, there is a reverse quality attribute. The existence of this attribute causes customer dissatisfaction. Conversely, the absence of this attribute will provide customer satisfaction (Lin, Yang, Chan, \& Sheu, 2010).

Kano model has drawbacks that prevent the company from accurately assessing quality attributes by considering the level of importance of the items. Moreover, there are some examples of research using Kano method in the service company (Prawira, Iqbal, \& Kurniawati, 2012; Puspitasari et al., 2010; Ramadhan, Setyanto, \& Efranto, 2013; Soedjono, 2012). The six studies have a common goal of analyzing factors that affect customer satisfaction and improve service quality on each studied object.

Then, further development is carried out on the Kano model, so the Refined Kano model emerges as proposed by Yang (2005). It has become one of the choices of new models that are still rarely used. The Refined Kano model is more specific in categorizing customers' needs by taking into account the degree of importance of each assessed attribute. So, it becomes a better choice to determine the priority of quality improvement expected by the customers. Research using the Refined Kano model is done by Lin et al. (2010) and Sukwadi, Inderawati, and Lie (2015). Based on the previous research, the results indicate that not all attributes have the same role in customer satisfaction. By considering the role of each attribute and degree of importance, it can obtain the most appropriate improvement proposal to increase the value of customer satisfaction.

Kano model is improved by Yang (2005) by considering the importance of each service attribute. The four attribute categories of the Kano model are further developed into eighth attribute categories: very attractive and less attractive; high value-added and low value-added; critical and required; and potential and indifferent. These attribute categories are shown in Figure 2.

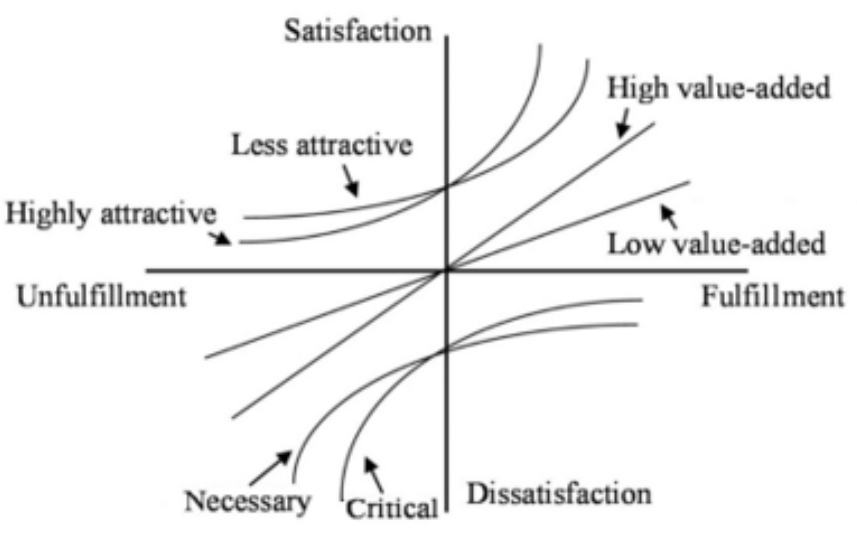

Figure 2 Refined Kano Model

(Source: Yang, 2015)

Importance Performance Analysis (IPA) is often used as a tool to analyze customer satisfaction and determine priorities for improving the quality of service needed to support the customer satisfaction analysis process (Aigbedo \& Parameswaran, 2004; Khoirunnisa, Setyanto, \& Oktavianty, 2014; Puspitasari et al., 2010; Sukwadi et al., 2015). Some of these studies integrate the IPA method with other methods, such as Servqual, QFD, and Kano Models. IPA is also used to determine priorities for improvements that need to be done by the company. The combination of Kano and IPA is a new tool for diagnosing the skills and attributes of service quality attributes in providing specific strategies for each category (Paraschivescu \& Cotîrleț, 2012). There are four categories in the IPA method (Yang, 2005), as seen in Figure 3. First, excellent attributes are considered necessary by customers. The performance of these attributes has resulted in customer satisfaction. Second, to be improved attributes are also considered important to customers. However, the attribute performance has not met customers' expectations or satisfaction. Third, surplus attributes are thought to be less important to customers. However, these attributes have provided 
high customer satisfaction. Fourth, care-free attributes have low or fewer customers' expectation values and result in low satisfaction scores.

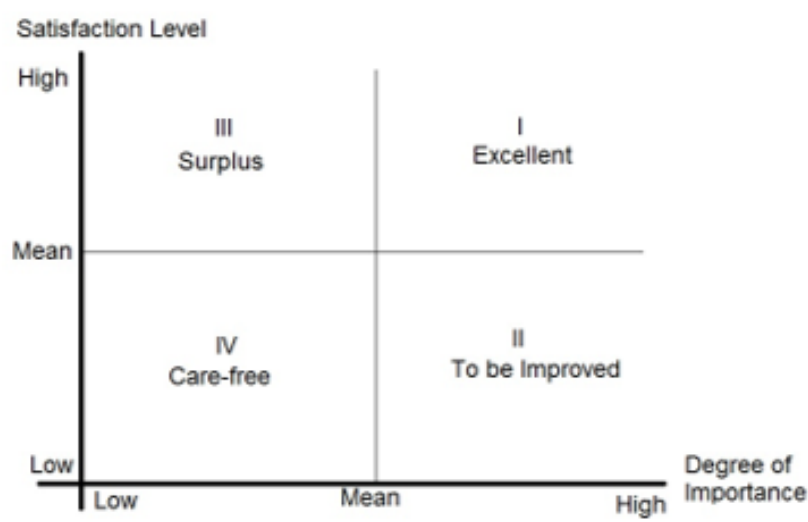

Figure 3 Importance Performance Analysis Matrix (Source: Yang, 2015)

According to Sukwadi et al. (2015), the IPA method is used to direct the service quality in implementing business strategy according to the most dominant priority of customers' interests. Therefore, this method can be a research supporter to determine the improvement priority in the object studied to produce a well-targeted improvement strategy and increase the number of customers.

Quality Function Deployment (QFD) is an oftenused method in planning quality improvement and product development. In service quality research, the QFD method is used as one of the tools in determining corrective steps following customers' needs (Puspasari, Setyanto, \& Himawan, 2014; Soedjono, 2012). Hence, QFD can describe the technical steps of improvement as the recommendation to increase the service quality of Grab Bike Indonesia. The QFD method focuses on customers' specifications for a service (Voice of Customer (VOC)). A tool in QFD that can be used for quality improvement is the House of Quality (HOQ) matrix. It is interconnected to determine customers' desires and technical parameters of a product or service. This matrix is created by preparing the VOC table, which is then translated into technical language for its realization through a technical response. Then, the correlation between each attribute and the target of each attribute is made and compared with competitors in the same field. Making the HOQ matrix can be useful to improve the quality of existing services with targets that must be achieved and priority service improvements that must be carried out. Figure 4 shows the shape and content of the HOQ matrix (İçtenbaş \& Eryilmaz, 2011).

HOQ matrix includes several contents. First, it is customer requirements. The customers' needs for products or services based on VOC are obtained from market observations, Kano model analysis, interviews, or other methods. The sidebar lists the level of customer importance for each attribute on a scale of 1 to 5 (1= very unimportant; $5=$ very important). Second, the competitive assessment contains a value of 1 to 5 ( $1=$ very inadequate; $5=$ very fulfilling). It is a measure of current service performance to customers' needs. It is also a value of 1 to 5 for competitors' service performance. Third, technical requirements consist of design characteristics or technical responses to meet customer requirements. The results of design characteristics are based on consideration of each customer's needs. Fourth, the relationship matrix shows the value of the relationship strength between customer requirements and technical requirements, using values of 1 for a weak relationship, 3 for a moderate relationship, and 9 for a strong relationship. Fifth, the correlation matrix indicates a strong and weak correlation between each design characteristic, consisting of a positive and negative relationship. No correlation means that the increase or decrease of one design characteristic has no impact or relationship to the increase or decrease of another design characteristic. Sixth, technical priorities contain the ranking of each customer's needs. It is obtained from the calculation of the influence of the customer's needs (Verawati, 2013).

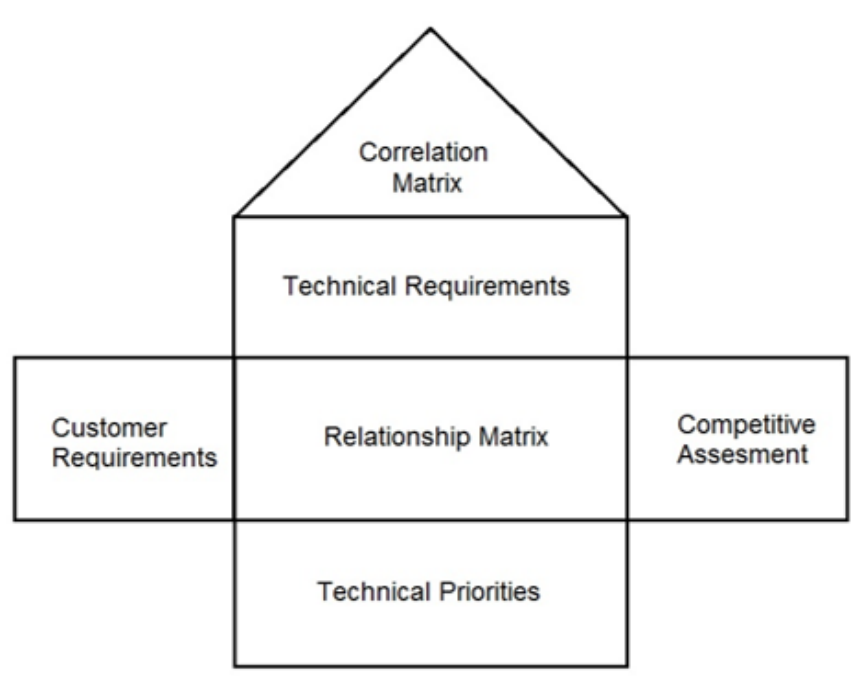

Figure 4 House of Quality matrix (Source: İçtenbaş \& Eryilmaz, 2011)

\section{METHODS}

The research uses non-probability sampling. According to Sugiyono (2011), non-probability sampling does not provide equal opportunities for each population element to be elected as a sample. The research considers limiting the population's age (between 18-50 years old) and knowledge and experience (at least more than two times of using the online rides) in choosing sample to avoid any sampling mistakes that potentially occur as a result of choosing a random sample. 
The type of sampling used is quota sampling. It is a technique for determining population samples that have certain characteristics to the desired amount of quota. The period of sampling was done in the earliest January - March 2019. Based on Supranto (2001), a good sample size can be determined by multiplying the number of questions in the questionnaire by five to ten. There are 36 questions in the questionnaire. The determination of the samples number of the research is through 36 questions multiplies 5 (36 questions $\times$ $5=180$ respondents). Therefore, the samples are 180 respondents. The respondents are customers of Grab Bike Indonesia in Jakarta.

The research applies both quantitative and qualitative approaches by conducting several supporting methods to collect data. First, there is an observation. The research monitors, studies, and apprehends problems in users of transportation service by Grab Bike Indonesia. Second, the questionnaire contains a list of questions regarding the problems of transportation services. It is distributed to respondents who are the customers of Grab Bike Indonesia. The questionnaire uses the Likert scale, which is widely used to scale the responses in survey research. Respondents specify their satisfaction or dissatisfaction level from 1 (the lowest) to 5 (the highest) on the scale. Third, the literature review uses several books and other scientific references related to the research. Fourth, the research also uses the company's official website to obtain the current information of the company's profile, vision and mission, history, and the number of transportation service users.

There are steps to achieve the research objectives. First, the research determines service quality attributes for the transportation sector. The research adopts the quality of transportation service attributes by Pagano and McKnight (1983). Second, the questionnaire is made based on the quality attributes of transportation services that have been determined. The attributes have been processed and adjusted to the type of transportation service studied. Third, questionnaires are distributed to 180 respondents who are the samples to get a picture of the nature of the population as a whole. The validity and reliability of collected data are tested. The rigor and strength of research are a function of the reliability and validity tests associated with the research (Morris \& Burkett, 2011).

\section{RESULTS AND DISCUSSIONS}

Servqual analysis compares the importance and customer satisfaction level by analyzing the gap score of each assessed service quality attribute. Table 1 (see Appendices) shows that the value of customer satisfaction is still below the expected value. Some attributes have a high gap score. Attributes with high gap scores have a gap above the average. The average value of the gap score is obtained from the average gap score of the perceived customer satisfaction value and the expected importance level. It is $-0,67$. Then, Table 2 (see Appendices) shows the attributes with gap scores above the average, sorted from the highest to the lowest. The perceived customer satisfaction is under the expected value. It shows the existence of customer dissatisfaction due to the lack of fulfillment of customers' expectations to the performance of the attribute at this time. Therefore, the company needs to fix the performance of the attribute.

After completing the Servqual analysis and calculating the gap scores, Kano model analysis is required to assess the functional and dysfunctional forms of the service attributes based on the distributed Kano questionnaire result. In the Kano model, service attributes in category $\mathrm{O}$ show that the service attribute will increase customer satisfaction if the performance of attributes increases. It will certainly provide additional value to the company if the attribute performance continues to improve. The company needs to pay attention to the attributes in category $\mathrm{O}$ because if the performance of these attributes decreases, the level of customer satisfaction will also decrease. In addition, several attributes are classified in category A. This type of service attribute is often referred to as the pleasure attributes. The attributes in category A will affect the level of customer satisfaction. If the performance of attributes increases, customer satisfaction will also increase. However, if there is a decrease in the performance of attributes, it will not reduce customer satisfaction. Lastly, there are several attributes in category I. In this category, the presence or absence of an attribute will not affect the level of customer satisfaction.

Refined Kano model distinguishes the importance level of each Kano category that has been divided. It determines the important role of each assessed attribute against the level of customer satisfaction. The importance determination of these attributes is assessed by comparing each service attribute's average level of importance according to respondents with the total average level of attribute importance. From this comparison, it can distinguish attributes that are classified as high and low importance. The classification can show the size of the influence in the attributes to customer satisfaction (see Table 3 in Appendices).

There are 22 service attributes that are classified as a high value-added category. The attributes included in this category have a high contribution to customer satisfaction. Therefore, the company must continually strive to improve and maintain the good performance of each attribute in this category. The other attributes belong to the other Refined Kano category, like low value-added. This category does not contribute to providing customer satisfaction. However, it does not mean that the company can ignore the attributes because it can also develop customer dissatisfaction. There are also attributes in the category of less attractive. It means that the attributes have little attractiveness for the customers. The attributes that are classified as less attractive can be removed if it costs a lot. Then, there is a care-free category. There are four service attributes in this category. The attributes can 
be removed for cost considerations. The attributes do not significantly affect customer satisfaction because they are considered less important.

For improvements, it is important to consider the things that most influence the increase in customer satisfaction. The IPA method considers the influence of attributes, and it describes the attributes using a Cartesian diagram (see Figure 5 in Appendices). It is divided into four quadrants, namely surplus, care-free, to be improved, and excellent.

Attributes categorized in excellent quadrant have high importance and satisfaction. It is necessary to maintain the good performance of each attribute in this quadrant. In addition, several attributes appear to approach the intersection line between excellent and to be improved quadrant. Therefore, strict control or safeguarding of these attributes is needed. It will be better if improvements to the attributes are made. Next, to be improved quadrant contains attributes that are considered to have a high importance value. However, the value of customer satisfaction with the performance of the attributes is currently below average. It can cause customer dissatisfaction. Improvements are highly needed for each of the attributes in this quadrant. The company must put the priority of improvement and focus on the attributes.

Meanwhile, the surplus is a quadrant that contains less important attributes by the customers, but implementing these attributes has provided a high level of satisfaction. In IPA Cartesian diagram, there are three attributes in the surplus category. However, these attributes approach the intersection line between the excellent and surplus quadrant. The attributes have the potential to be considered important for customers, so the company still needs to pay attention to the three attributes. The last quadrant is care-free. It shows the attributes that have low importance and satisfaction value. The attributes classified as care-free are considered to have no effect on customer satisfaction. Companies do not need to pay special attention to these attributes. It can be seen that several attributes approach the quadrant intersection line. It indicates the potential of these attributes to be considered important or expected by the customer. Companies need to maintain good performance for the attributes that customers potentially expect.

Based on the previous analysis, the research has identified the attributes that influence customer satisfaction, attributes that performed below customers' expectations, and priority in the improvements to service attributes. The following analysis is the technical improvement that the company can make. The priority steps to improve Grab Bike transportation service attributes are determined in accordance with customers' needs. So, improvements in attribute performance will be made. The improvement is expected to increase the value of the company's services quality.

QFD analysis starts with the identification of VOC. The data are obtained from the questionnaire result that has been processed and analyzed using
Servqual, Kano and Refined Kano model, and IPA. From the methods, the research obtains the attributes that need to be improved to meet customers' expectations. The attributes are included in the list of the VOC in HOQ matrix (see Figure 6 in Appendices).

HOQ matrix is initially carried out by connecting each VOC with the existing technical response. It is filled with symbols that indicate the strength of the relationship. A correlation analysis is also performed between each technical response. There are several explanations for the contents of the HOQ that have been compiled.

First, competitive assessment (benchmarking) shows the comparison of Grab Bike Indonesia's current performance rate to its competitors, namely Gojek and Uber. The current position of Grab Bike overall is still below Gojek and above Uber. From 16 service attributes, 9 attributes are exceeded by Gojek, 6 attributes are exceeded by Grab Bike Indonesia, and 1 attribute is exceeded by Uber. Grab must compete to gain and maintain customer loyalty by providing better service quality for each service attribute, especially the performance of attributes that are currently below the competitors.

Second, it is the relationship between VOC and technical response. The customers' needs can be fulfilled by technical response design. Each technical response has different relationship strengths in supporting the performance of service attributes. The HOQ matrix uses several symbols that indicate the strength of the relationship between customers' needs and technical responses. Each strength point of the relationship will be added up to determine the priority things the company must do.

Third, the relationship between each technical response. In the technical correlation section of the HOQ matrix, some arranged technical responses can support each other because they are positively related, and there is no negative link. Fourth, there is technical importance. Based on the relationship formed between customers' needs and technical response, the total importance of each technical response is obtained from the strength of the relationship between customers' needs and technical response multiplied by the importance value of each customer's needs. Each value that has been obtained will be added to other obtained customers' needs in the same type of technical response. In the end, the weighted importance value is from the total result to indicate the priority improvements that must be done.

Moreover, the priority technical response of improvements that the company must carry out is explained as follows. First, the company should provide regulations that drivers must obey. The regulations improve the service attribute performance. The rules should be bound and strict that it is mandatory for each driver. This aspect can be supported by the other technical response, such as providing a driving speed standard, regulations in maintaining attitude and politeness, picking up customers within a certain period (max. $15 \mathrm{~min}$ ), rules to minimize rejection of 
orders (every refusal will have a penalty), and others.

Second, the company should provide driving standards. It is the compilation of a standard for drivers to maintain customer safety and comfort during the trip. Standards must be made to cover every aspect that affects travel comfort, such as vehicle speed (max. $60 \mathrm{~km} / \mathrm{h}$ ) and adherence to traffic rules. Third, there are strict sanctions for each violation of rules. Based on the regulations that have been made, if the drivers violate these rules, they will be given a strict sanction. For example, every committed violation will be sanctioned and given minus points as a form of warning. If the drivers continue to make mistakes, at a certain number of minus points, the drivers can be fired by the company.

Fourth, there should be initial training for the drivers. Before the work begins, the driver is required to attend the initial training. The training aims to provide rules and material that must be understood as essential, such as company value, vision, and mission. It is intended that each driver can work with one goal in line with the company's goals.

Fifth, to overcome the lack of drivers' knowledge on every route that must be traversed, it is necessary for them to use GPS properly. Drivers need to be taught how to use GPS to reach every destination they want to go to. It can be done through the initial training for each driver.

Sixth, the company should provide an easy way for customers' feedbacks. The company provides a forum that makes it easy for customers to express opinions and criticisms for each service. The provided feedback forum should be easy for customers to see and write after using the service. Every statement submitted will be accommodated and counted to be something that the company must consider or correct.

Seventh, the drivers can study the destination route. Before making a pickup or delivery process, the drivers must be able to understand the taken route. Drivers need to study the intended direction, road conditions, traffic jams, and others. It aims to maintain a smooth journey to the destination.

Eighth, the company should follow up on the customers' feedback. The company must pay attention to every criticism and suggestion submitted by customers. Critics and suggestions indicate the dissatisfaction felt by customers from the services. Therefore, the company is obliged to follow up on the criticism and suggestion submitted within the specified time, such as a maximum of seven days for following up.

Ninth, drivers are required to maintain good behavior. The politeness and good behavior of the drivers are the aspects that make customers convenient in using the services. The company needs to emphasize that every driver should behave properly and politely. For its implementation, the company can make it an obligation for every driver. Strict sanctions will be given to a violation of this thing.

Tenth, the company can give rewards to the best drivers. Rewards can be an encouragement and appreciation for the drivers to keep providing the best service. The reward is judged by the drivers' performance obtained from every rate given by the customers.

Eleventh, there is the availability of pickup time request service. At this time, the company does not provide pickup time request services. For this reason, it is recommended that the company can provide this form of service, so customers can make requests at what time they want to be picked up.

Twelfth, there should be a periodic check of attribute completion. Before starting the daily activity, drivers need to check the completeness of the attributes. By checking the completeness of this attribute, drivers can also find out when they need to replace or add the attribute.

Thirteenth, a first aid kit should be available on the vehicle. It is a precautionary measure and first aid in an emergency. For example, it is needed when the customer falls from a vehicle or there is a minor accident. It is necessary for the company to provide a first-aid kit for every vehicle.

Fourteenth, there should be confirmation of pickup and current position. Drivers need to contact the customers to ensure their location to pick up at the right place. In addition, it is necessary to let the customers know the drivers' position when going to the pickup location, so the customers can certainly wait for the drivers' arrival.

Last, there should be periodic vehicle checks and maintenance. Preventive measures can be taken by checking and maintaining vehicles regularly to avoid obstacles during the trip, such as leaky tires, engine damage, and others. For example, once a month, the drivers check their vehicles.

\section{CONCLUSIONS}

The research aims to evaluate the quality of transportation services at Grab Bike Indonesia. The research applies non-probability sampling by limiting sample's age, knowledge, and experience in using online rides to avoid any sampling mistakes. The research is done to 180 respondents, who are the customers of Grab Bike Indonesia in Jakarta. The research applies Servqual method and finds 36 service attributes needed by the customers of online motorcycle ride services. There are gaps between customers' expectations and satisfaction. Based on the research result, the company should improve the service by focusing on the main problems of customer dissatisfaction.

According to the summary result of categorization of Kano, Refined Kano, and IPA, five attributes should be prioritized for improvement. Those attributes are notification of delays or cancelation of service, being picked up at time selected by the traveller, knowledge of the route, receptiveness to users' complaints and suggestions, and procedure for follow-up on complaints. 
Furthermore, according to QFD analysis, the research finds technical steps of improvement. The company should provide regulations that drivers must obey, driving standards, strict sanctions for every violation of rules, initial training for drivers, utilization of GPS properly, easy way for customers' feedback, studying the destination routes, follow-up the customers' feedback. The company should also give rewards to the best drivers, offer the availability of pickup time request service, conduct a periodic check of attribute completion, provide first aid kit on the vehicle, confirm pickup and driver's current position information, and provide periodic vehicle check and maintenance. Moreover, drivers are required to maintain their good behavior.

The prior points are the recommendation to solve service issues in the Grab Bike to improve the service quality following the customers' needs. The research may be the first research of services provided by Grab Bike during the period of survey in early January - March 2019. However, the findings of the present research may not generalize Grab Bike Indonesia as a whole. It is expected to decrease the problems of customer dissatisfaction that occurs and improve company quality. In addition, future research with other methods is needed to obtain a comprehensive analysis of online-based ride-hailing services.

\section{ACKNOWLEDGMENT}

The publication was partially supported by Direktorat Penelitian \& Pengabdian Masyarakat (PPM), Telkom University.

\section{REFERENCES}

Aigbedo, H., \& Parameswaran, R. (2004). Importanceperformance analysis for improving quality of campus food service. International Journal of Quality and Reliability Management, 21(8), 876896. https://doi.org/10.1108/02656710410551755

Badan Pusat Statistik Provinsi DKI Jakarta. (2019a). Jumlah kendaraan bermotor menurut jenis kendaraan (unit) di Provinsi DKI Jakarta 2018-2020. Retrieved from https://jakarta.bps.go.id/indicator/17/786/1/jumlahkendaraan-bermotor-menurut-jenis-kendaraan-unitdi-provinsi-dki-jakarta.html

Badan Pusat Statistik Provinsi DKI Jakarta. (2019b). Jumlah penduduk Provinsi DKI Jakarta menurut kelompok umur dan jenis kelamin 2018-2020. Retrieved from https://jakarta.bps.go.id/indicator/12/111/1/jumlahpenduduk-provinsi-dki-jakarta-menurut-kelompokumur-dan-jenis-kelamin.html

İçtenbaş, B. D., \& Eryilmaz, H. (2011). Quality function deployment as a strategic planning tool. International Journal of Social Sciences and Humanity Studies, 3(2), 73-82.

Khoirunnisa, A. F., Setyanto, N. W., \& Oktavianty, O. (2014). Analisis kepuasan pelanggan menggunakan atribut pelayanan prima dengan mengintegrasikan Importance Performance Analysis (IPA) dan Quality Function Deployment (QFD) (Studi kasus: PT. Sang Hyang Seri (Persero)-Malang). Jurnal Rekayasa dan Manajemen Sistem Industri, 2(4), 740-749.

Lin, S. P., Yang, C. L., Chan, Y.H., \& Sheu, C. (2010). Refining Kano's 'quality attributes-satisfaction' model: A moderated regression approach. International Journal of Production Economics, 126(2), 255-263. https://doi.org/10.1016/j.ijpe.2010.03.015

Morris, E., \& Burkett, K. (2011). Mixed methodologies: A new research paradigm or enhanced quantitative paradigm. Online Journal of Cultural Competence in Nursing and Healthcare, 1(1), 27-36.

Pagano, A. M., \& McKnight, C. E. (1983). Quality of service in special service paratransit: The users' perspective. Transportation Research Record, 934, 14-23.

Paquette, J., Cordeau, J. F., \& Laporte, G. (2009). Quality of service in dial-a-ride operations. Computers and Industrial Engineering, 56(4), 1721-1734. https:// doi.org/10.1016/j.cie.2008.07.005

Paraschivescu, A. O., \& Cotîrleț, A. (2012). Kano model. Economy Transdisciplinarity Cognition, 15(2), 116124.

Prawira, D. J., Iqbal, M., \& Kurniawati, A. (2012). Usulan perbaikan kualitas layanan maskapai penerbangan X Menggunakan integrasi QFD dan model Kano. Jurnal Teknik Industri, 13(2), 142-150. https://doi. org/10.22219/jtiumm.vol13.no2.142-150

Puspasari, D., Setyanto, N. W., \& Himawan, R. (2014). Upaya peningkatan kualitas pelayanan perpustakaan dengan integrasi service quality dan quality function deployment (Studi kasus: Perpustakaan Umum dan Arsip Kota Malang). Jurnal Rekayasa dan Manajemen Sistem Industri, 2(6), 1251-1261.

Puspitasari, N. B., Suliantoro, H., \& Kusumawardhani, L. (2010). Analisis kualitas pelayanan dengan menggunakan integrasi Importance Performance Analysis (IPA) dan model Kano (Studi kasus di PT. Perusahaan Air minum Lyonnaise Jaya Jakarta).J@ ti Undip: Jurnal Teknik Industri, 5(3), 185-198.

Ramadhan, E. W., Setyanto, N. W., \& Efranto, R. Y. (2013). Analisis kepuasan konsumen terhadap kualitas pelayanan dengan penerapan Importance Performance Analysis (IPA) dan model Kano (Studi kasus pada Asrama Mahasiswa Griya Brawijaya Universitas Brawijaya Malang). Jurnal Rekayasa dan Manajemen Sistem Industri, 1(2), 183-193.

Sugiyono. (2011). Metode penelitian kualitatif, kuantitatif dan $R \& D$. Bandung: Alfabeta.

Soedjono, M. (2012). Analisis dan usulan perbaikan kualitas layanan menggunakan integrasi metode Servqual, model Kano, dan QFD di Warung Ipang Cabang Mayjend Sungkono Surabaya. Calyptra: Jurnal Ilmiah Mahasiswa Universitas Surabaya, 1(1), 1-19.

Sukwadi, R., Inderawati, W., \& Lie, V. (2015). Pengembangan strategi perbaikan kualitas layanan taman hiburan Dunia Fantasi Ancol. Journal of Industrial Engineering and Management Systems (JIEMS), 8(1), 55-69.

Supranto, J. (2001). Pengukuran tingkat kepuasan 
pelanggan untuk menaikkan pangsa pasar. Jakarta: Rineka Cipta.

The World Factbook. (2017a). Economy overview. Retrieved from https://www.cia.gov/the-worldfactbook/countries/world/\#economy

The World Factbook. (2017b). GDP - Composition, by sector of origin. Retrieved from https://www.cia. gov/the-world-factbook/field/gdp-composition-bysector-of-origin

Verawati, V. (2013). Analisis prioritas pengembangan kualitas layanan penunjang Akademik Universitas Bunda Mulia dengan metode quality function deployment (Thesis). Universitas Bunda Mulia.

Yang, C. C. (2005). The refined Kano's model and its application. Total Quality Management \& Business Excellence, 16(10), 1127-1137. https://doi. org/10.1080/14783360500235850 


\section{APPENDICES}

Table 1 Servqual Analysis for Grab Attributes

\begin{tabular}{|c|c|c|c|c|}
\hline Dimension & Attributes & $\begin{array}{l}\text { Expectation } \\
\text { Score }\end{array}$ & $\begin{array}{l}\text { Perception } \\
\text { Score }\end{array}$ & Gap Score \\
\hline \multirow[t]{4}{*}{ Reliability } & $\begin{array}{l}\text { Notification of delays or cancelation of the } \\
\text { service }\end{array}$ & 4,64 & 3,76 & $-0,88$ \\
\hline & Waiting time for picking up & 4,57 & 3,94 & $-0,63$ \\
\hline & On-time in arriving at the destination & 4,51 & 3,83 & $-0,68$ \\
\hline & Few delays while on the vehicle & 4,32 & 3,75 & $-0,57$ \\
\hline \multirow[t]{4}{*}{ Comfort } & Guaranteed seat & 4,62 & 3,95 & $-0,67$ \\
\hline & Condition and cleanliness of the vehicle & 4,61 & 3,91 & $-0,70$ \\
\hline & Smoothness of the ride & 4,68 & 3,90 & $-0,78$ \\
\hline & $\begin{array}{l}\text { Sheltered waiting areas for pickups that are } \\
\text { away from home }\end{array}$ & 4,16 & 3,55 & $-0,61$ \\
\hline \multirow{4}{*}{$\begin{array}{l}\text { Convenience } \\
\text { of making a } \\
\text { reservation }\end{array}$} & Accommodation to change the reservation & 4,24 & 3,58 & $-0,66$ \\
\hline & $\begin{array}{l}\text { Being picked up at time selected by the } \\
\text { traveller }\end{array}$ & 4,56 & 3,79 & $-0,77$ \\
\hline & $\begin{array}{l}\text { Convenience of the return reservation } \\
\text { procedure }\end{array}$ & 4,67 & 4,03 & $-0,64$ \\
\hline & Shortness of reservation time & 4,46 & 3,81 & $-0,65$ \\
\hline \multirow[t]{5}{*}{ Extend of service } & Total number of hours of service & 4,51 & 3,87 & $-0,64$ \\
\hline & No or few restrictions on where vehicles go & 4,39 & 3,73 & $-0,66$ \\
\hline & Service on evenings & 4,61 & 3,96 & $-0,65$ \\
\hline & Service on weekends & 4,59 & 4,05 & $-0,54$ \\
\hline & Low rate of turning down reservations & 4,36 & 3,48 & $-0,88$ \\
\hline \multirow[t]{6}{*}{ Vehicle Access } & Ability to pass every terrain & 4,39 & 3,84 & $-0,55$ \\
\hline & Height of the seat & 3,65 & 3,44 & $-0,21$ \\
\hline & Ability to travel far & 4,44 & 3,87 & $-0,57$ \\
\hline & $\begin{array}{l}\text { Assistance in getting from vehicle to } \\
\text { destination }\end{array}$ & 3,61 & 3,27 & $-0,34$ \\
\hline & Assistance in carrying packages & 4,33 & 3,69 & $-0,64$ \\
\hline & $\begin{array}{l}\text { Short distance from house or destination to the } \\
\text { vehicle }\end{array}$ & 4,42 & 3,78 & $-0,64$ \\
\hline \multirow[t]{5}{*}{ Safety } & Low probability of personal assault & 4,68 & 3,95 & $-0,73$ \\
\hline & Low probability of falling & 4,68 & 4,01 & $-0,67$ \\
\hline & $\begin{array}{l}\text { Availability of passenger attributes (helmets, } \\
\text { masks, jackets, and raincoats) }\end{array}$ & 4,68 & 3,87 & $-0,81$ \\
\hline & Drivers' obedience to traffic rules & 4,66 & 3,89 & $-0,77$ \\
\hline & Low probability of a traffic accident & 4,69 & 3,96 & $-0,73$ \\
\hline \multirow{5}{*}{$\begin{array}{l}\text { Driver's } \\
\text { Characteristics }\end{array}$} & Ability to handle medical emergencies & 4,63 & 3,88 & $-0,75$ \\
\hline & Knowledge of the route & 4,72 & 3,80 & $-0,92$ \\
\hline & Courtesy and friendliness & 4,71 & 3,91 & $-0,80$ \\
\hline & $\begin{array}{l}\text { Familiarity with habits and needs of the } \\
\text { individual user }\end{array}$ & 4,09 & 3,67 & $-0,42$ \\
\hline & Neatness and professionalism & 4,39 & 3,73 & $-0,66$ \\
\hline \multirow[t]{3}{*}{ Responsiveness } & Ease of getting clear information on service & 4,51 & 3,87 & $-0,64$ \\
\hline & $\begin{array}{l}\text { Receptiveness to users' complaints and } \\
\text { suggestions }\end{array}$ & 4,60 & 3,79 & $-0,81$ \\
\hline & Procedure for follow-up on complaints & 4,61 & 3,66 & $-0,95$ \\
\hline
\end{tabular}


Table 2 The Attributes with High Gap Scores

\begin{tabular}{clc}
\hline No & Attributes & Gap Score \\
\hline 1 & Procedure for follow-up on complaints & $-0,95$ \\
2 & Knowledge of the route & $-0,92$ \\
3 & Low rate of turning down reservations & $-0,88$ \\
4 & Notification of delays or cancelation of service & $-0,88$ \\
5 & Availability of passenger attributes (helmets, masks, jackets, and raincoats) & $-0,81$ \\
6 & Receptiveness to users' complaints and suggestions & $-0,81$ \\
7 & Courtesy and friendliness & $-0,80$ \\
8 & Smoothness of the ride & $-0,78$ \\
9 & Drivers' obedience to traffic rules & $-0,77$ \\
10 & Being picked up at time selected by the traveler & $-0,77$ \\
11 & Ability to handle medical emergencies & $-0,75$ \\
12 & Low probability of a traffic accident & $-0,73$ \\
13 & Low probability of personal assault & $-0,73$ \\
14 & Condition and cleanliness of the vehicle & $-0,70$ \\
15 & On-time in arriving at the destination & -0.68 \\
16 & Guaranteed seat & $-0,67$ \\
17 & Low probability of falling & $-0,67$ \\
\hline
\end{tabular}


Table 3 The Classification of the Influence from Customer Satisfaction Attributes

\begin{tabular}{|c|c|c|c|c|}
\hline Dimension & Attributes & Kano & Refined Kano & IPA \\
\hline \multirow[t]{4}{*}{ Reliability } & $\begin{array}{l}\text { Notification of delays or cancelation of } \\
\text { service }\end{array}$ & $\mathrm{O}$ & High Value-Added & To be improved \\
\hline & Waiting time for pick up & $\mathrm{O}$ & High Value-Added & Excellent \\
\hline & On-time in arriving at the destination & $\mathrm{O}$ & High Value-Added & Excellent \\
\hline & Few delays on the vehicle & A & Less Attractive & Care-Free \\
\hline \multirow[t]{4}{*}{ Comfort } & Guaranteed seat & $\mathrm{O}$ & High Value-Added & Excellent \\
\hline & Condition and cleanliness of the vehicle & $\mathrm{O}$ & High Value-Added & Excellent \\
\hline & Smoothness of the ride & $\mathrm{O}$ & High Value-Added & Excellent \\
\hline & $\begin{array}{l}\text { Sheltered waiting areas for pickups that are } \\
\text { away from home }\end{array}$ & I & Care-Free & Care-Free \\
\hline \multirow{4}{*}{$\begin{array}{l}\text { Convenience of } \\
\text { Making Reservation }\end{array}$} & Accommodation to change the reservation & A & Less Attractive & Care-Free \\
\hline & $\begin{array}{l}\text { Being picked up at time selected by the } \\
\text { traveler }\end{array}$ & $\mathrm{O}$ & High Value-Added & To be improved \\
\hline & $\begin{array}{l}\text { Convenience of the return reservation } \\
\text { procedure }\end{array}$ & $\mathrm{O}$ & High Value-Added & Excellent \\
\hline & Shortness of reservation time & $\mathrm{O}$ & Low Value-Added & Surplus \\
\hline \multirow{5}{*}{$\begin{array}{l}\text { Extension of } \\
\text { Service }\end{array}$} & Total number of hours of service & $\mathrm{O}$ & High Value-Added & Excellent \\
\hline & No or few restrictions on where vehicles go & $\mathrm{O}$ & Low Value-Added & Care-Free \\
\hline & Service on evenings & $\mathrm{O}$ & High Value-Added & Excellent \\
\hline & Service on weekends & $\mathrm{O}$ & High Value-Added & Excellent \\
\hline & Low rate of turning down reservations & $\mathrm{O}$ & Low Value-Added & Care-Free \\
\hline \multirow[t]{6}{*}{ Vehicle Access } & Ability to pass every terrain & A & Less Attractive & Surplus \\
\hline & Height of the seat & I & Care-Free & Care-Free \\
\hline & Ability to travel far & A & Less Attractive & Surplus \\
\hline & $\begin{array}{l}\text { Assistance in getting from vehicle to } \\
\text { destination }\end{array}$ & I & Care-Free & Care-Free \\
\hline & Assistance in carrying packages & $\mathrm{O}$ & Low Value-Added & Care-Free \\
\hline & $\begin{array}{l}\text { Short distance from house or destination to } \\
\text { the vehicle }\end{array}$ & $\mathrm{O}$ & Low Value-Added & Care-Free \\
\hline \multirow[t]{5}{*}{ Safety } & Low probability of personal assault & $\mathrm{O}$ & High Value-Added & Excellent \\
\hline & Low probability of falling & $\mathrm{O}$ & High Value-Added & Excellent \\
\hline & $\begin{array}{l}\text { Availability of passenger attributes } \\
\text { (helmets, masks, jackets, and raincoats) }\end{array}$ & $\mathrm{O}$ & High Value-Added & Excellent \\
\hline & Drivers' obedience to traffic rules & $\mathrm{O}$ & High Value-Added & Excellent \\
\hline & Low probability of a traffic accident & $\mathrm{O}$ & High Value-Added & Excellent \\
\hline \multirow{5}{*}{$\begin{array}{l}\text { Drivers' } \\
\text { Characteristics }\end{array}$} & Ability to handle medical emergencies & $\mathrm{O}$ & High Value-Added & Excellent \\
\hline & Knowledge of the route & $\mathrm{O}$ & High Value-Added & To be improved \\
\hline & Courtesy and friendliness & $\mathrm{O}$ & High Value-Added & Excellent \\
\hline & $\begin{array}{l}\text { Familiarity with habits and needs of the } \\
\text { individual user }\end{array}$ & I & Case-Free & Case-Free \\
\hline & Neatness and professionalism & A & Less Attractive & Case-Free \\
\hline \multirow[t]{3}{*}{ Responsiveness } & Ease of getting clear information on service & $\mathrm{O}$ & High Value-Added & Excellent \\
\hline & $\begin{array}{l}\text { Receptiveness to users' complaints and } \\
\text { suggestions }\end{array}$ & $\mathrm{O}$ & High Value-Added & To be improved \\
\hline & Procedure for follow-up on complaints & $\mathrm{O}$ & High Value-Added & To be improved \\
\hline
\end{tabular}




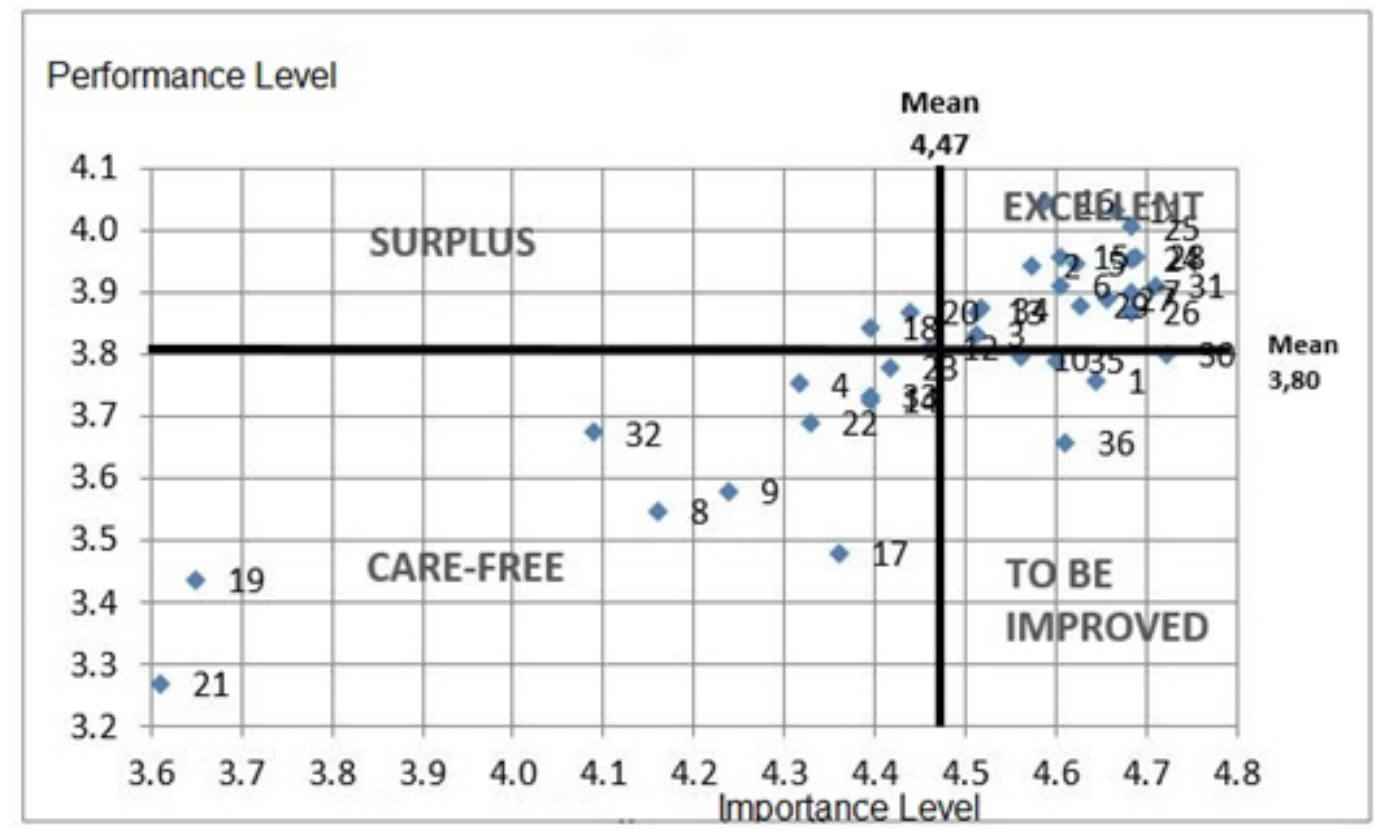

\section{No. Attribute}

1 Notification of delays or cancelation of service

19 Height of the seat

2 Waiting time for pick up

20 Ability to travel far

3 On-time in arriving at the destination

21 Assistance in getting from vehicle to destination

4 Few delays on the vehicle

22 Assistance in carrying packages

5 Guaranteed seat

Short distance from house or destination to the vehicle

6 Condition and cleanliness of the vehicle

Low probability of personal assault

7 Smoothness of the ride

8 Sheltered waiting areas for pickups that are away from

Low probability of falling home

Availability of passenger attributes (helmets, masks, jackets, and raincoats)

9 Accommodation to change the reservation

Drivers' obedience to traffic rules

10 Being picked up at time selected by the traveller

Low probability of a traffic accident

11 Convenience of the return reservation procedure

Ability to handle medical emergencies

12 Shortness of reservation time

Knowledge of the route

3 Total number of hours of service

Courtesy and friendliness

14 No or few restrictions on where vehicles go

32 Familiarity with habits and needs of the individual user

15 Service on evenings

16 Service on weekends

17 Low rate of turning down reservations

33 Neatness and professionalism

34 Ease of getting clear information on service

35 Receptiveness to users' complaints and suggestions

18 Ability to pass every terrain

Figure 5 Cartesian Diagram of Importance Performance Analysis 


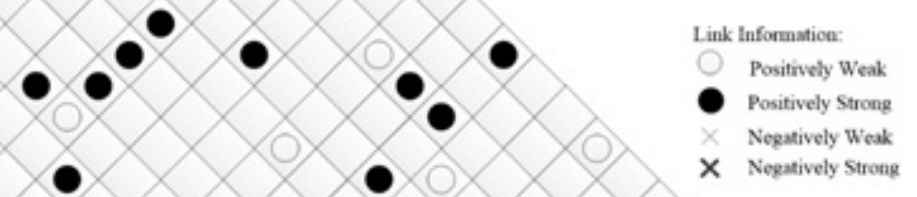

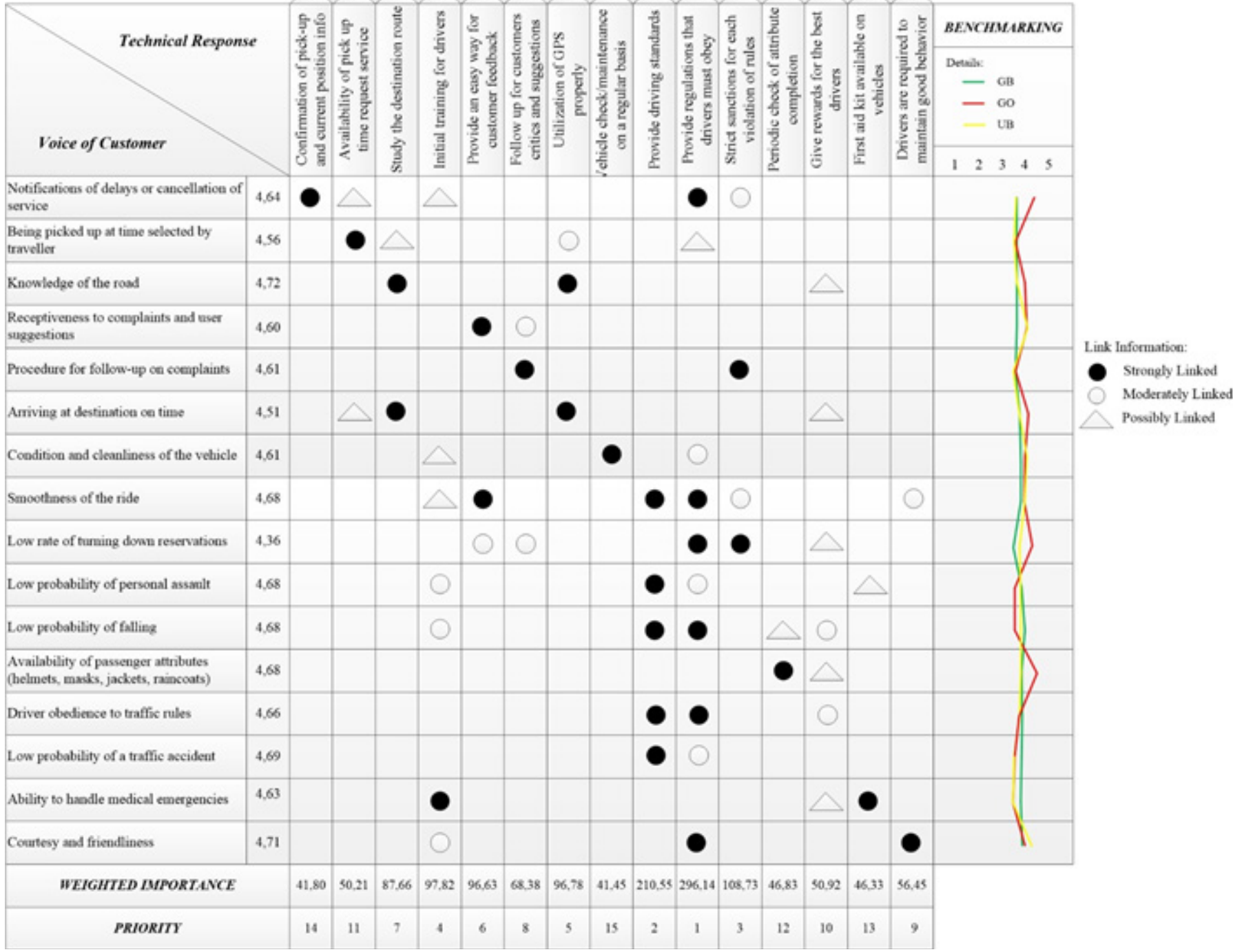

Figure 6 House of Quality for Transportation Service Attributes in Grab Bike 